\title{
The distribution of diatom flora in ice caves of the northern Yukon Territory, Canada: relationship to air circulation and freezing
}

\author{
Bernard Lauriol ${ }^{1}$, Clément Prévost and Denis Lacelle
}

\begin{abstract}
:
Lauriol B., Prévost C. and Lacelle D. 2006. The distribution of diatom flora in ice caves of the northern Yukon Territory, Canada: relationship to air circulation and freezing. International Journal of Speleology, 35 (2), 83-92. Bologna (Italy). ISSN $0392-6672$

In the late 1980's and early 1990's, various media in karst environments in the Northern Yukon Territory were examined for their diatom content. Cryogenic cave calcite powders, grus and various ice formations (ice plugs, ice stalagmites and floor ice) were collected from three freezing caves and one slope cave to make an inventory of the diatom content, and to explain the spatial distribution of the diatoms within the caves. The results show that approximately $20 \%$ of diatoms in the caves originate from external biotopes and habitats (e.g., river, lake, stream), with the remaining $80 \%$ of local origin (i.e., from subaerial habitats near cave entrances). The results also indicate that the greater abundance of diatoms is found in the larger caves. This is explained by the fact that the air circulation dynamics are much more important in caves that have a larger entrance. Also grus, ice plugs and ice stalagmites have the lowest diatom diversity, but greater relative abundance, indicative of growth in specific habitats or under specific conditions. Overall, these results are a contribution to the study of particles transport in ice caves.
\end{abstract}

Keywords: diatoms, ice cave, slope cave, freezing cave, cryogenic cave calcite, grus

Received 28 April 2006; Revised 19 May 2006; Accepted 5 June 2006

\section{INTRODUCTION}

Diatoms are microscopic unicellular algae that range in size from approximately $5 \mu \mathrm{m}$ to $500 \mu \mathrm{m}$ and live in moist environments, including soils (Barber \& Haworth, 1981). The diatom group Bacillariophyceae is characterized by an exquisitely sculptured cell wall composed entirely of silica (Lewin, 1962). This siliceous structure is very resistant to post-depositional alteration, thereby allowing these microscopic algae to be preserved as microfossils in sediments or other media (Haworth, 1980; Battarbee, 1986). Many studies have discussed the presence of diatoms in caves (e.g. Hoeg, 1946; Kol, 1957; Claus, 1955, 1962a, 1962b, 1964; Palik, 1960; van Landingham, 1965, 1966, 1967; Fukuchi, 1967; Mason-Williams, 1967; Gounot, 1968; Dobat, 1970; Carter, 1971; St.Clair \& Rushforth, 1978; Bahls 1981; St.Clair et al. 1981; Camburn, 1982; Kashima et al.,1987; Rushforth et al., 1984; Dayner \& Johansen, 1991). However, these studies have focused mainly on compiling diatom taxa lists, only a few, (Roldan et al., 2004) explained their origin and distribution within the caves. It can be disputed that the presence of diatoms in caves is limited to the zone near the entrance within reach of

1) Corresponding author: B. Lauriol (blauriol@uottawa.ca) Department of Geography, University of Ottawa, 60 University St., Ottawa ON K1N 6N5, Canada. daylight and that the possibility of finding diatoms in deeper sections of caves is considerably reduced due to the absence of light, which prevents their in situ growth. Therefore, one can readily argue in favour of an allochtonous origin of diatom assemblages found in sediment, ice or other media in zones outside the reach of daylight in caves.

This paper is the first study that deals specifically with the origin and distribution of diatoms found in ice formations and cryogenic calcite deposits in freezing and slope caves located in the northern Yukon Territory, Canada (Fig. 1). Freezing caves, glacières (Balch, 1900) or ice caves are caves that contain seasonal and / or perennial ice. Slope caves, as defined by Mitter (1983), are recognized as having: i) a linear form that is up to tens of meters long; ii) walls that are modelled by mechanical weathering; iii) a floor that dips toward the entrance, and iv) debris on the floor that exhibits sorted polygons and striped features, which are unique to periglacial environments. A slope cave can be considered a rock shelter of a few meters long, but rock shelters are not limited to permafrost regions and are known to have various origins (Sweeting, 1972; Ford \& Williams, 1989).

The possibility of finding diatoms in ice and calcite deposits in caves in periglacial environment is a challenge since ice can be harmful for the preservation 
of diatoms. Nevertheless, studies from glacier and sea ice (Kellogg \& Kellogg, 1996; Thomas, 2004) have shown that the aerophilous species of diatoms can attach themselves to the surface of the ice (epicryotic) or grow within fissures or air and water bubbles in the ice (endocryotic). The mineral salts $\left(\mathrm{CaCO}_{3}\right.$ and $\left.\mathrm{SiO}_{2}\right)$ and water coating the surface of the ice formations can likely provide the necessary nutrients for their growth and survival, if there is enough light. Moreover, diatoms that live in the presence of ice have been shown to secrete an extra-cellular polysaccharide substance that enables them to be embedded onto the ice surface. This substance also has a cryoprotectant role, protecting diatom cells from damage by freezing (Thomas \& Dieckmann, 2003).

\section{STUDY AREA}

\section{Physiography}

The study area is located within the zone of continuous permafrost in the northern Yukon Territory, Canada (Fig. 1). More specifically, the sampling sites are situated in the Tsi-it-toh-Choh and Bear Cave ranges. The regional climate is characterized by a cold continental regime. The mean annual air temperature presently recorded at the Mayo meteorological station (504 $\mathrm{m}$ above sea level), located $350 \mathrm{~km}$ south of the study area, is $-3.1 \pm 2.4^{\circ} \mathrm{C}$ (January $\mathrm{T}^{\circ} \mathrm{C}$ : $-25.8^{\circ} \mathrm{C}$; July $\mathrm{T}^{\circ} \mathrm{C}: 16^{\circ} \mathrm{C}$ ) and annual precipitation amounts to $313 \mathrm{~mm}$, with $65 \%$ falling as rain (Environment Canada, 2004). Old Crow meteorological station (270 $\mathrm{m}$ a.s.1.), located $125 \mathrm{~km}$ north of the Tsi-it-tohChoh and Bear Cave ranges, reports a mean annual air temperature of $-10^{\circ} \mathrm{C}$ (January $\mathrm{T}^{\circ} \mathrm{C}$ : $-35^{\circ} \mathrm{C}$; July $\mathrm{T}^{\circ} \mathrm{C}: 15^{\circ} \mathrm{C}$ ) and receives only $215 \mathrm{~mm}$ of precipitation annually, half falling as rain (Environment Canada, 2004). The modern vegetation is subarctic, dominated by black spruce forest in the valley and by tundra on the plateau.

The Tsi-it-toh-Choh and Bear Cave ranges are a platform composed of limestone and dolomite faulted in the late Cretaceous to early Tertiary (Norris, 1980). The platform measures $40 \mathrm{~km}$ by $5 \mathrm{~km}$ and rises to $1219 \mathrm{~m}$ a.s.1, and 500 to $600 \mathrm{~m}$ above the surrounding lowlands (Fig. 2). There are short, horizontally-oriented caves inherited from the Tertiary which are exposed in the upper part of canyon walls, fed by intermittent streams cutting the mountainous plateau. It is inside some of these caves that annual and perennial ice and calcite-rich deposits were sampled.

\section{The ice caves (Grande Caverne, Caverne'85 and Caverne des Méandres)}

The sampled ice caves are: Grande Caverne Glacée, herein referred to as Grande Caverne (66 $42^{\prime}$ N; $139^{\circ} 18^{\prime}$ $\mathrm{W})$, Caverne'85 $\left(66^{\circ} 46^{\prime} \mathrm{N} ; 1^{\prime} 39^{\circ} 17^{\prime} \mathrm{W}\right)$ and Caverne des Méandres $\left(66^{\circ} 42^{\prime} \mathrm{N} ; 1^{\circ} 39^{\circ} 17^{\prime} \mathrm{W}\right)$. These caves are located in the Tsi-it-toh-Choh Range and extend between 750 and $950 \mathrm{~m}$ a.s.1. (Lauriol et al., 1997). Grande Caverne is one of the largest openings in the area, varying in width from $5 \mathrm{~m}$ to $8 \mathrm{~m}$, approaching 3 $\mathrm{m}$ in height and $90 \mathrm{~m}$ in length (Fig. 3). Caverne'85 is narrower (1-2 m), shorter $(40 \mathrm{~m})$ and reaches almost

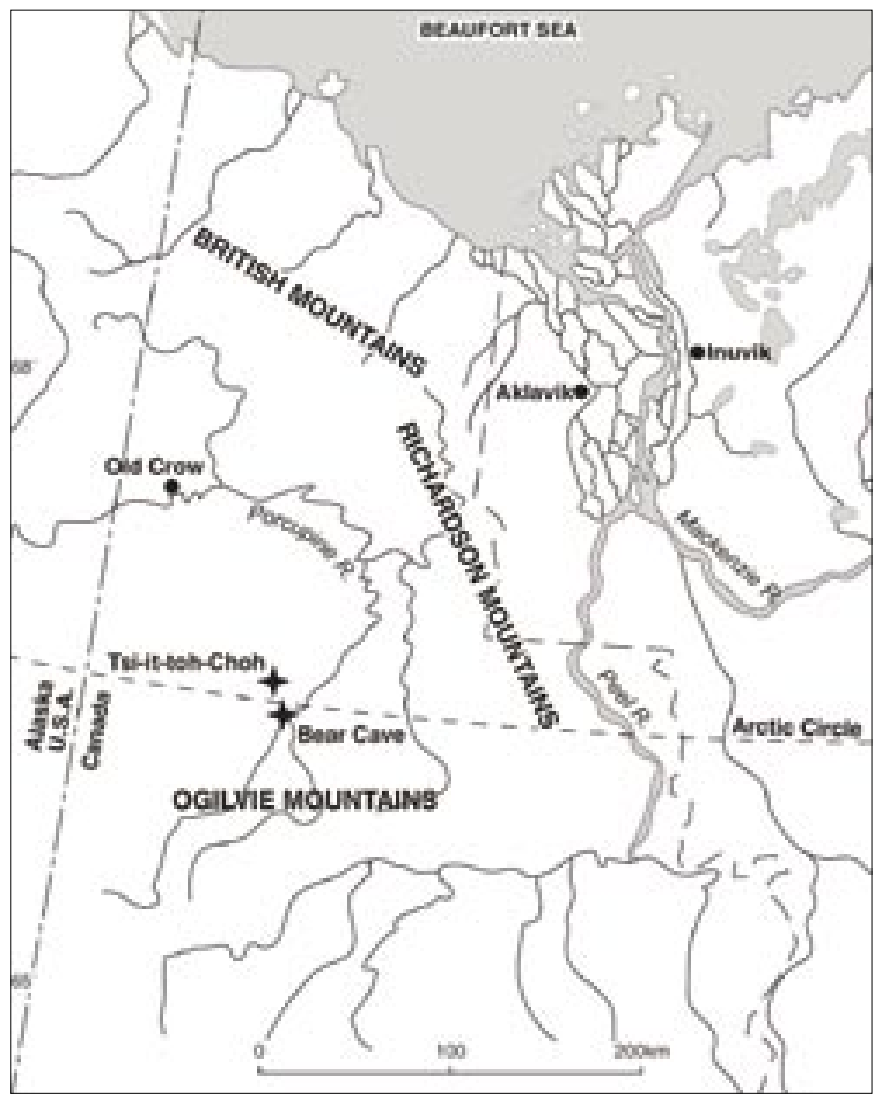

Fig. 1. Location of Tsi-it-toh-Choh and Bear Cave ranges. Northern Yukon, Canada

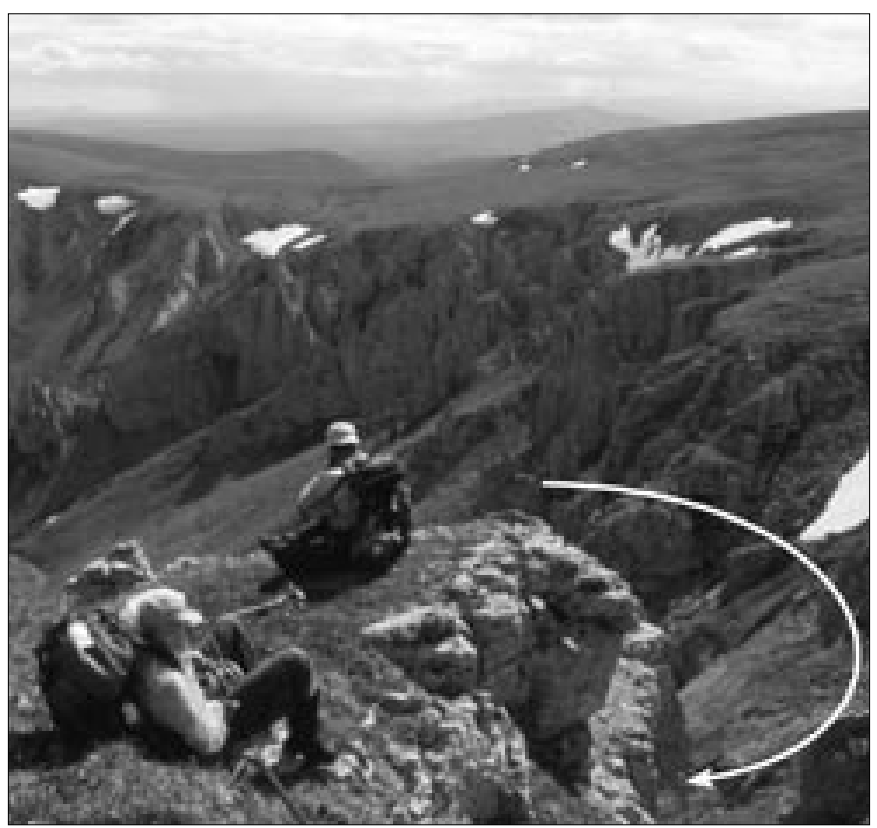

Fig. 2. Landscape near Caverne'85, (the arrow shows the location of Caverne'85). Northern Yukon Territory, Canada.

$4 \mathrm{~m}$ in height (Fig. 4). Caverne des Méandres is 100 $\mathrm{m}$ long, 2-3 $\mathrm{m}$ wide and 2 to $4 \mathrm{~m}$ high (Fig. 5). Figure 6 presents a synthesis of the different types of cave studied in this article with a representation of air circulation during the summer season, as described in Lauriol et al. (1988).

The age, microclimate, macro-remains and cryogenic cave calcite deposits of the ice caves have been described in detail by Prévost (1992), Clark \& Lauriol (1992) and Lauriol et al. (1988, 1995, 2001). Figure 3 shows the temperature and relative humidity meas- 


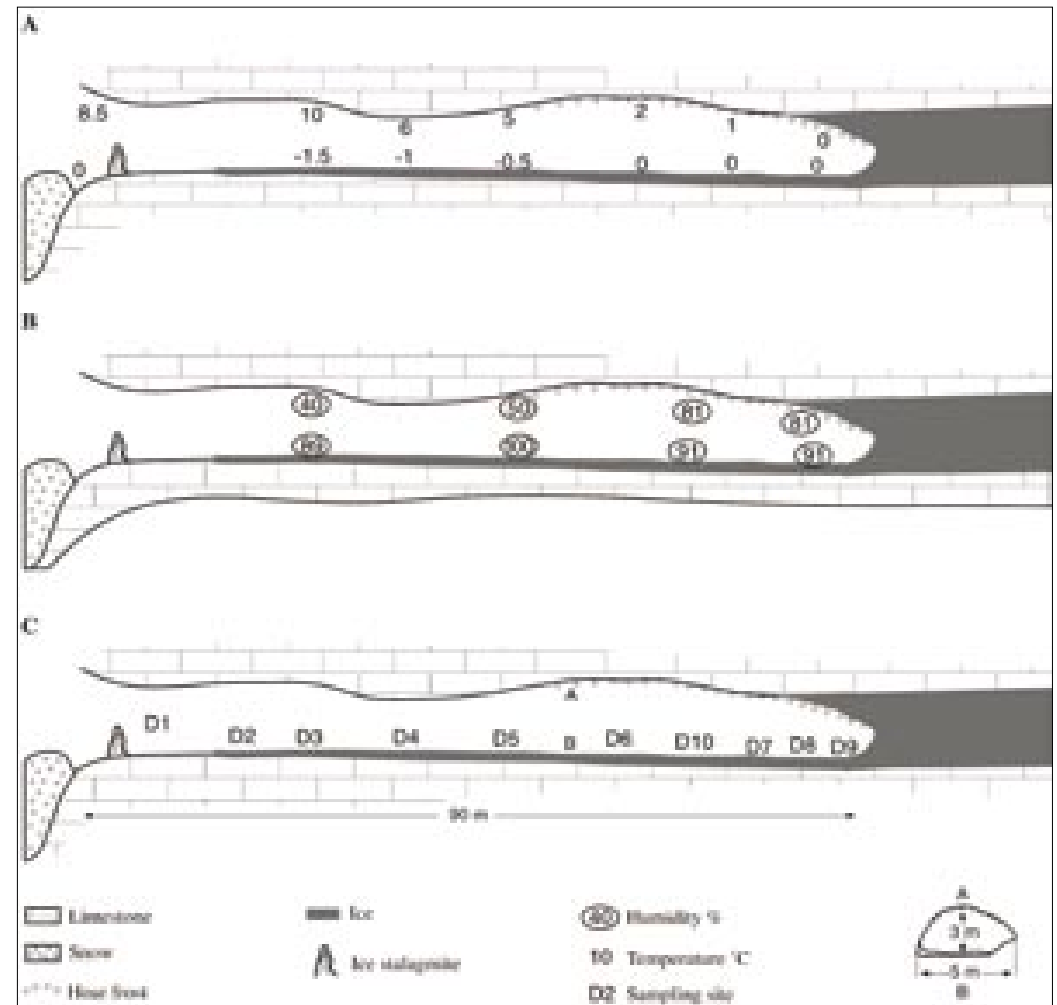

Fig. 3. Topography. A: temperature, B: relative humidity and C: sampled sites in Grande Caverne, Yukon Territory, Canada. The climatic measurements were taken on June $29^{\text {th }} 1992$.

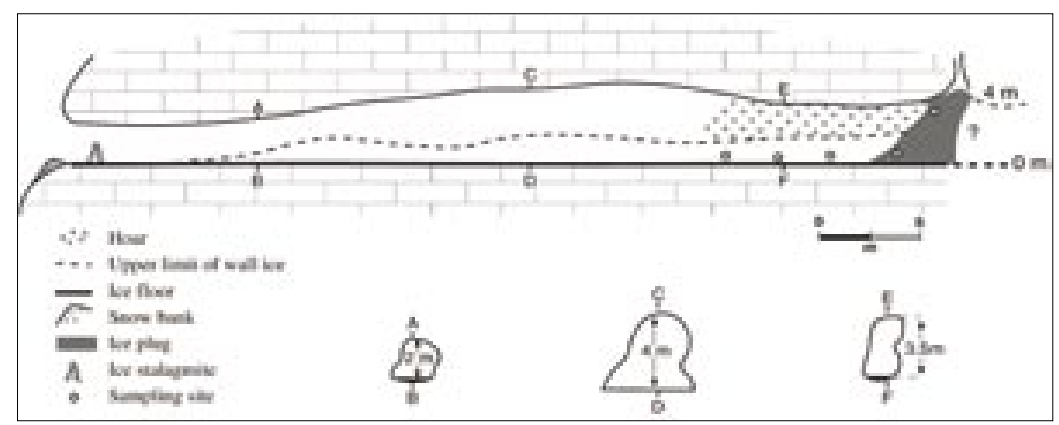

Fig. 4. Topography, ice formations, and sampling sites in Caverne'85, Yukon Territory, Canada.

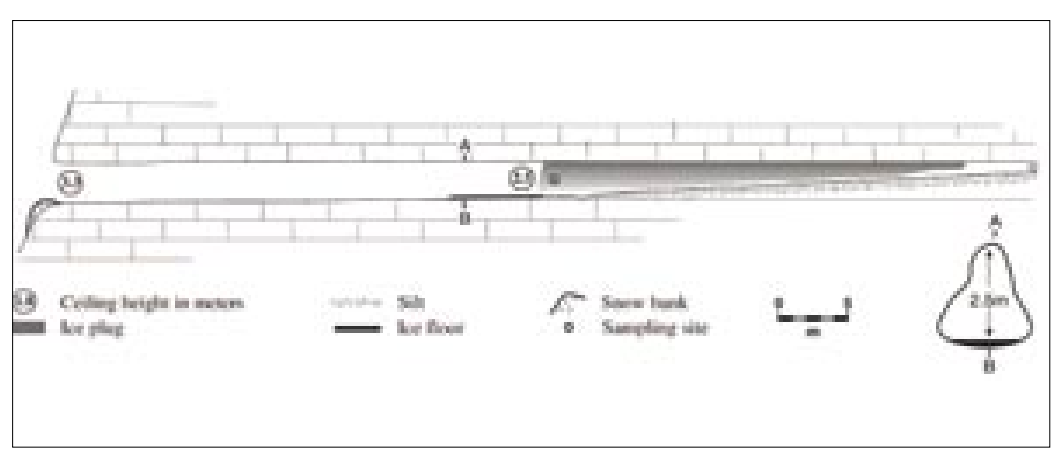

Fig. 5. Topography, ice formations and sampling site in Caverne des Méandres, Yukon Territory, Canada.

\begin{tabular}{|c|c|c|c|}
\hline D-2 & D-3 & D-6 & D-7 \\
\hline Diadesmis contenta & D. contenta & Achanthes kryophila & A. minutissima \\
\hline D. perpusilla & D. perpusilla & D. minutissima & Denticula tenuis \\
\hline Encyonema minutum & Orthoseira roeseana & D. contenta & D. contenta \\
\hline O. roeseana & Pinnularia balfouriana & O. roeseana & Hannaea arcus \\
\hline P. borealis & & P balfouriana & P. intermedia \\
\hline
\end{tabular}

Table 2. Detail of diatom flora in Grande Caverne from the sites represented in Figure 3. ured in June 1990 in Grande Caverne. The air temperature, which progressively decreases within the cave, is warmer along the roof and colder just above the floor. The relative humidity increases within the cave and is highest near the ice plug and above the floor, and lowest near the entrance due to the increasing hygrometric capacity of warmer air. Based on these results, it appears that during the summer, the cold dense air trapped inside the cave flows outwards along the horizontal to near-horizontal floor of the caves and is replaced by warm air entering along the roof. As the warm humid air cools by way of contact with the colder rock surfaces, which is less than $0^{\circ} \mathrm{C}$, its relative humidity rapidly rises to $100 \%$, leading to condensation and hoar ice formation (Fig. 7).

At a certain distance into the caves, the hoar accumulates to form a perennial ice plug. The ice plug is in equilibrium with the modern July $0^{\circ} \mathrm{C}$ isotherm in the caves and the distance of the isotherm from the cave's entrance varies according to the diameter of the entrance: the greater the diameter, the deeper is the ice plug inside the cave. For example, with an entrance diameter of $4 \mathrm{~m}$, the ice plug inside Grande Caverne is found at a distance of $90 \mathrm{~m}$ inside the cave, whereas in Caverne des Méandres, which has an entrance diameter of $2 \mathrm{~m}$, the ice plug is found $30 \mathrm{~m}$ inside the cave (Fig.8). However, not all ice plugs result from the accumulation of hoar ice. Some ice plugs are formed by snow that enters into the cave through a vertical shaft that joins the main passage. This was observed in Caverne'85, where the passage terminates with an ice plug found at the base of a vertical shaft partially filled with snow. Generally, the ice plugs totally close passages in the cave, but a narrow passage can occasionally exist between the ice and the floor, as observed in Caverne des Méandres in July 1995.

Condensation on the walls in caves can also lead to dissolution of the limestone, either during condensation or during the thaw of the hoar ice. The exact nature of this process remains unknown, but probably approaches the one described by Tarhule-Lips \& Ford (1988), Zupan Hajna (2003) and Lacelle et al. (2004) in temperate and warmer caves. Cryogenic calcite powders result from the dissolution and precipitation of calcite. These cryogenic powders are commonly found on the surface of the various ice formations and on the floor of the caves. The processes related to the formation of the cryogenic calcite powders, which are released from the ice during sublimation, was ascribed to the freezing of bicarbonated water (Clark \& Lauriol, 1992; Lauriol et al., 2006). 


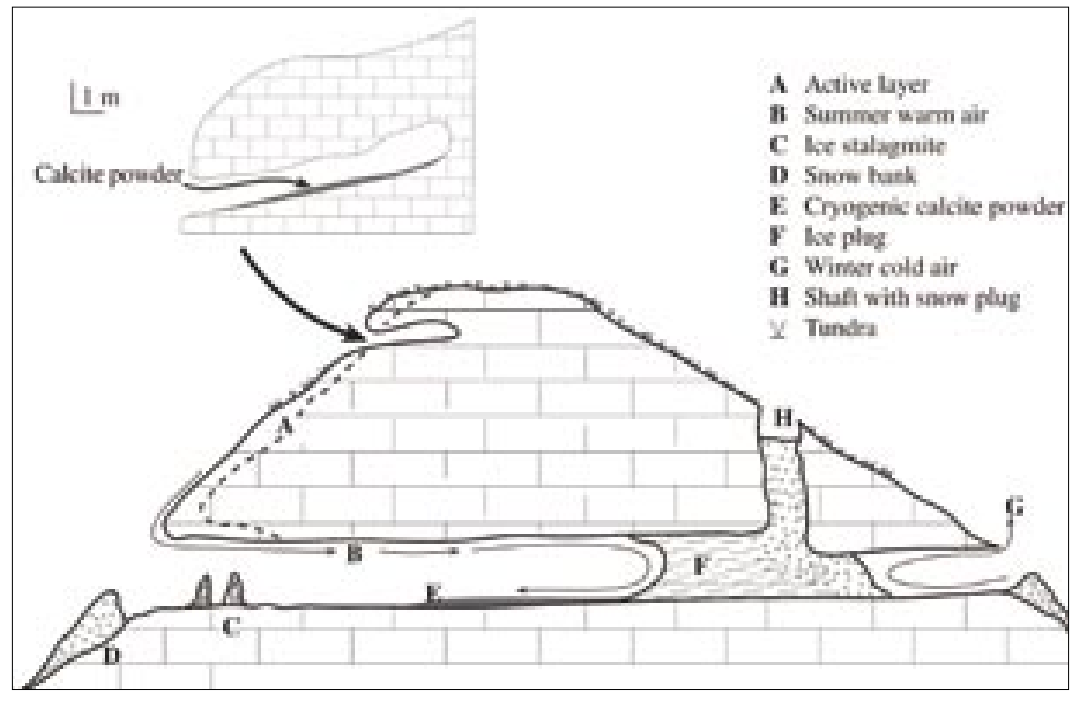

Fig. 6. A schematic representation of sampled caves for diatom analyses in Northern Yukon, Canada.

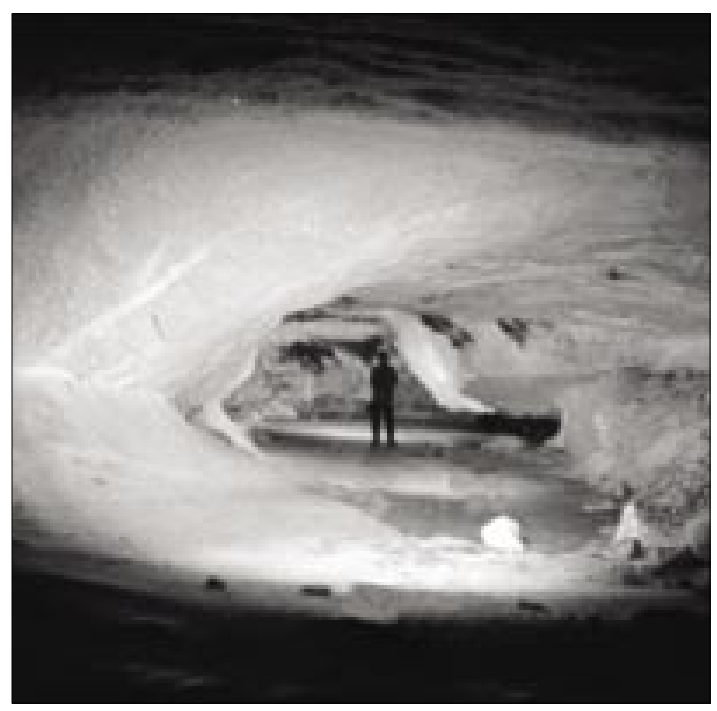

Fig.7. Hoar and ice floor in Grande Caverne. Northern Yukon Territory, Canada.

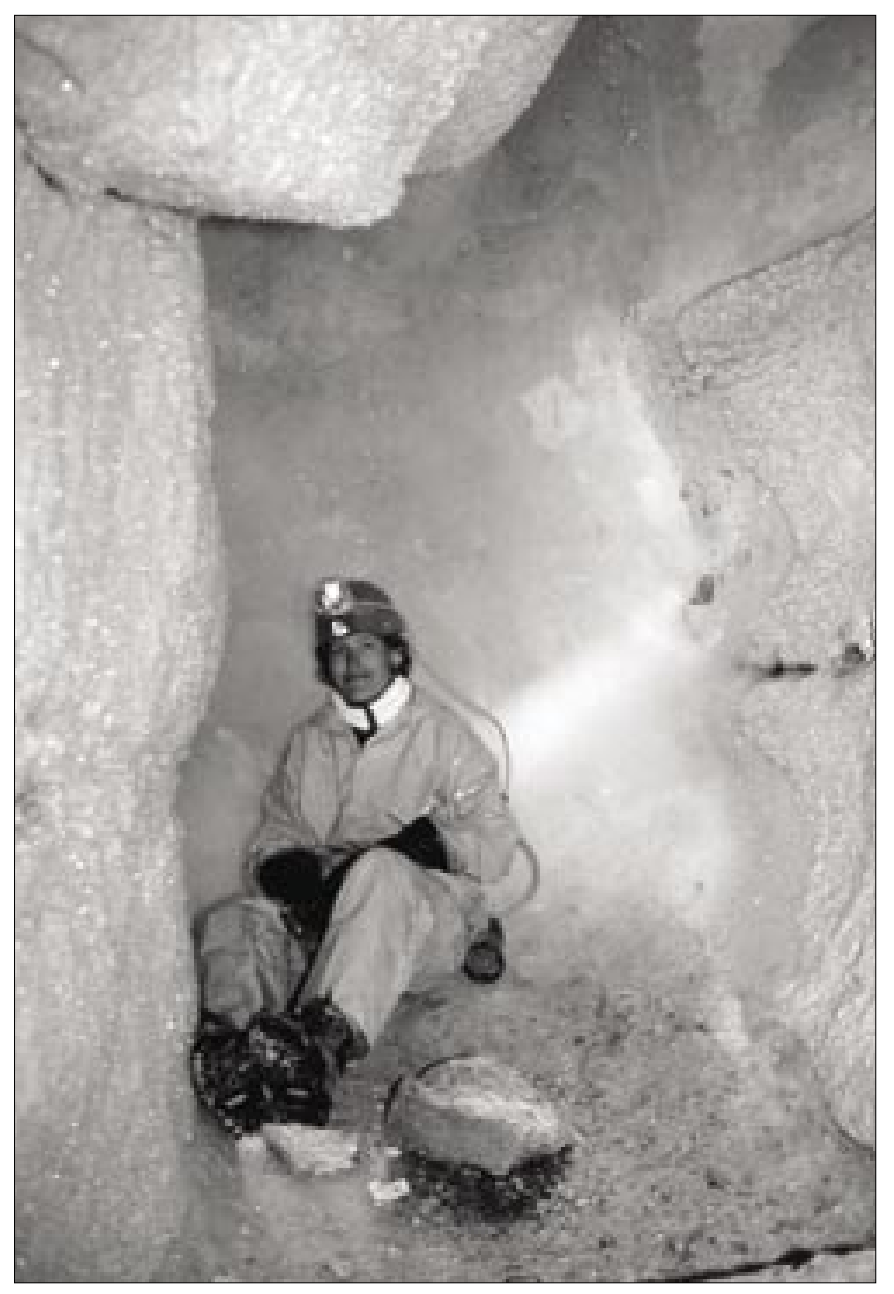

Fig 8. Ice plug in Caverne des Méandres. Northern Yukon Territory, Canada.

\section{The slope cave (PC-85)}

The sampled slope cave, PC-85 (66 $30^{\circ} \mathrm{N}$; $139^{\circ} 16^{\prime} \mathrm{W}$; $600 \mathrm{~m}$ a.s.1.), is located on an upright-standing rock outcrop on a south to south-eastern facing slope in the Bear Cave Range. The cave is small, measuring $7 \mathrm{~m}$ long and $1.2 \mathrm{~m}$ diameter. It rises slightly and ends at a blind-wall. Frost weathering and transport activity played an important role in the formation of the slope cave. A 3 to $5 \mathrm{~cm}$ thick greyish, calcite-rich sediment mixed with small rock fragments covers the floor of the cave. Mitter (1983) used the term "powder sinter" to describe this type of secondary carbonate deposit. The author probably made a mistake in proposing a new term, since the longestablished term for this type of weathering product is grus (Glossary of Geology, 2005). In PC-85, the grus occurs on the walls and floor of the cave, which are dusty during dry periods and muddy during wet periods.

Grus is different from the cryogenic calcite deposits. Its granulometry has a bimodal distribution, with a first mode in the silty class, around $30 \mu \mathrm{m}$, and a second in the sandy class, around $500 \mu \mathrm{m}$. The stable isotope of oxygen $\left(\delta^{18} \mathrm{O}\right)$ and carbon $\left(\delta^{13} \mathrm{C}\right)$ of the grus, presented in the $\delta$-notation, which is the normalized difference between the sample and a standard, i.e. $\delta^{18} \mathrm{O}=\left[\left({ }^{18} \mathrm{O} /{ }^{16} \mathrm{O}\right)_{\mathrm{spl}} /\left({ }^{18} \mathrm{O} /{ }^{16} \mathrm{O}\right)_{\mathrm{std}}-1\right] \cdot 1000 \%$ o, are $-2 \%$ o and $4 \%$ o respectively, which is similar to that of local bedrock but different to that of cryogenic cave calcite powders, which have $\delta^{13} \mathrm{C}$ values up to $17 \%$ (Clark $\&$ Lauriol, 1992). All of these elements indicate that the grus in PC-85 is a by-product of rock-surface weathering processes, most likely micro-gelivation or freeze/thaw cycles.

\section{Field sampling}

\section{METHODOLOGY}

In the late 1980's and early 1990's, samples of ice plugs, ice stalagmites, cryogenic calcite powders and grus were collected from caves located in Tsi-it-tohChoh and Bear Cave ranges. In Grande Caverne, one ice stalagmite (D1) located near the entrance, two samples from the ice plug located at the end of the cave (D8 and D9) and nine samples from the floor (three cryogenic calcite powders and six floor ice samples) were collected. In Caverne des Méandres, we collected two samples from the ice plug. In Caverne'85, three samples of cryogenic calcite powders, one ice stalagmite and two samples from the ice plug were collected. Finally, in the slope cave 
(PC-85), grus was collected from the floor.

The ice plugs, ice stalagmites and floor ice samples were collected using an ice axe, allowed to melt in the field and then poured in $250 \mathrm{ml}$ HDPE bottles. The water samples were kept cool and in the dark until shipment to Ottawa. Approximately 200-300 g of calcite-rich sediments (cryogenic calcite powders and grus) were collected from the floor of the caves, and stored in sterile plastic bags.

\section{Preparation of samples}

The preparation of samples for diatom analysis required the use of various chemicals to digest organic matter. The melted ice samples were first treated at room temperature with $30 \%$ hydrogen peroxide $\left(\mathrm{H}_{2} \mathrm{O}_{2}\right)$ followed by four to six cycles of washing with distilled water and centrifugating until all trace fold acids were removed. The calcite-rich deposits (cryogenic calcite powders and grus) were subjected to a $10 \%$ $\mathrm{HCl}$ treatment at room temperature until the reaction stopped, followed by four cycles of rinsing and centrifuging with distilled water. The purpose of the $\mathrm{HCl}$ treatment was to remove the calcium carbonate, thereby liberating the diatoms. Following the $\mathrm{HCl}$ treatment, residues were treated with a 1:1 mixture of boiling sulphuric $\left(\mathrm{H}_{2} \mathrm{SO}_{4}\right)$ and nitric $\left(\mathrm{HNO}_{3}\right)$ acids to remove organic materials.

Residues obtained from acid digestion were transferred into glass scintillation vials. Distilled water was added to obtain final aliquots of $20 \mathrm{ml}$. Various volumes of aliquots $(0.2$ to $1.0 \mathrm{ml})$ were pipetted onto $18 \times 18$ and $18 \times 40 \mathrm{~mm}$ glass coverslips, and dried on a slide warmed at $50^{\circ} \mathrm{C}$. The dried coverslips were mounted on permanent microscopic slides using Hyrax $^{\circledR}$ diluted with $20 \%$ toluene. Several slides were mounted for each sample using most of the $20 \mathrm{ml}$ aliquot (a small volume of each aliquot was kept as an archive).

The enumeration method used in this study differs somewhat from that routinely executed for sediments originating from diatom-rich environments, such as sediments collected in lakes and bogs. For every sample, mounted slides were entirely and systematically scanned in transects. All diatoms encountered were identified and enumerated to the species level whenever possible. The analysis allowed for the determination of the various diatom assemblages, species diversity and relative abundance. The results are presented in Table 1. If a species of diatom represented more than $80 \%$ of all diatoms on a slide, it was classified as abundant, if its abundance was less than $10 \%$, it was classified as rare and in-between it was classified as frequent.

\section{Identification}

Diatom identification was based on the compilations of Krammer \& Lange-Bertalot (1986, 1988, 1991), Lange-Bertalot \& Krammer (1989), Germain (1981), and Patrick \& Reimer $(1966,1975)$. The works of Foged $(1971,1981)$ and Hein $(1990)$ and the taxonomic revision of Round et al. (1990) were also consulted. The checklist of Hartley (1986) was used for synonymy and authority verifications, along with the workshop report of Hamilton et al. (1994) and the catalogue of van Landingham $(1966,1967)$.

\section{RESULTS AND INTERPRETATION Diatoms in ice plug}

The diatom assemblage contained in the ice plug of Caverne des Méandres and Grande Caverne (Table 1 - Column 4) is highly diversified with 37 species identified, but only a few diatom species are abundant, such as Achnanthes linearis, A. minutissima, Cymbella latens, C. microcephala and C. minuta. The other diatom species are either frequent or rare. The absence of any species-dominated assemblage and the dark environment suggest that the diatom species contained in the ice plug samples are allochthonous.

The diatom assemblage (17 species) in the ice plug in Caverne'85 (Table 1 - Column 5) consists of aerophilous diatoms dominated by Orthoseira dendroteres. Forms of Navicula (Diadesmis) contenta, parallela, biceps and Pinnularia balfouriana, which grow on arctic mosses and which are common in arctic lakes and ponds (Douglas \& Smol, 1994), are also present. Therefore, the diatom assemblage identified in the snow-built ice plug represents a mixed assemblage of aerophilus diatoms introduced by air flowing into the cave, while some were transported during the accumulation of snow at the base of the vertical shaft.

\section{Diatoms in ice stalagmite}

Twenty-nine diatom species were identified (Table 1 - Column 6) in the ice stalagmites collected in Grande Caverne and Caverne'85. The diatom assemblage is largely dominated by Navicula (Diadesmis) gallica var. perpusilla, an aerophilous diatom. Other aerophilous diatoms, which are also found in significant numbers, include Achnanthes kryophila and N.(Diadesmis) gallica. These species are well-adapted to the subaerial humid conditions prevailing near the entrance of the caves, where the light intensity is very low (Krammer \& Lange-Bertalot, 1986).

\section{Diatoms in floor ice and cryogenic calcite powders}

The diatoms identified in the floor ice and cryogenic calcite powders sampled on the floor of Grande Caverne and Caverne' 85 are presented in Table 1 (Column 1 and 2). The diatom assemblage does not vary between Grande Caverne and Caverne'85 and between the different sample locations. For example, the diatom assemblage in the floor ice samples D2 and D3, located $16 \mathrm{~m}$ from the entrance of Grande Caverne, is very similar to the diatom species in samples D6 and D7, located $88 \mathrm{~m}$ inside the cave (Table 2).

In total, 58 diatom species were identified in Grande Caverne and 30 species in Caverne'85. The diatoms species are slightly less abundant in the floor ice samples $(n=40)$ than in the cryogenic calcite powder samples $(n=49)$, since in the latter, the diatoms are liberated from the ice during sublimation of the floor ice, which leads to the accumulation of cryogenic calcite powders on the floor of the caves. As a result, the diatoms trapped in the floor ice and cryogenic calcite 


\begin{tabular}{|c|c|}
\hline DIATOM FLORA & CC-Gc \\
\hline Achnanthes biasolettiana Grun. & \\
\hline A. flexella (Kütz.) Brun & - \\
\hline A. fragilarioïdes Petersen & \\
\hline A. kryophila Petersen & \\
\hline A. laevis Østr. & \\
\hline A. linearis (W. Sm.) Grun. & \\
\hline A. marginulata Grun. & \\
\hline A. microcephala (Kütz.) Cleve & \\
\hline A. minutissima Kütz. & - \\
\hline A. petersenii Hust. & \\
\hline Achnanthes spp. & - \\
\hline Amphora inariensis Krammer & - \\
\hline A. lybica Ehrenb. ex Kütz. & \\
\hline A. pediculus (Kütz.) Grun. & \\
\hline Amphora spp. & \\
\hline Aulacoseira sp. (cf. granulata) & \\
\hline Brachysira vitrea (Grun.) Ross & - \\
\hline Caloneis spp. & - \\
\hline Cocconeis placentula Ehrenb. & \\
\hline Cocconeis spp. & - \\
\hline Cymbella affinis Kütz. & \\
\hline C. amphicephala Naegeli ex Kütz. & \\
\hline C. aspera (Ehrenb.) H. Perag. & - \\
\hline C. cistula (Ehrenb.) Kirchn. & - \\
\hline C. descripta (Hust.) Kram. \& L.-B. & \\
\hline C. latens Krasske & \\
\hline C. microcephala Grun. & \\
\hline C. minuta Hilse ex Rabenh. & + \\
\hline C. silesiaca Bleisch ex Rabenh. & \\
\hline Cymbella spp. & ++ \\
\hline Denticula tenuis Kütz. & - \\
\hline D. tenuis var. crassula (Naegeli ex Kütz.) West & - \\
\hline Diatoma hyemale (Roth) Heiberg & \\
\hline D. mesodon (Ehrenb.) Kütz. & • \\
\hline D. tenue $\mathrm{Ag}$. & - \\
\hline Diploneis spp. & - \\
\hline Didymosphenia geminata (Lyngb.) M. Schmidt & ++ \\
\hline Eunotia paludosa Grun. & \\
\hline E. praerupta Ehrenb. & ++ \\
\hline E. praerupta var. bidens (Ehrenb.) Grun & • \\
\hline Eunotia spp. & - \\
\hline Fragilaria spp. & + \\
\hline Gomphonema acuminatum var. elongatum W. Sm. & - \\
\hline G. angustatum (Kütz.) Rabenh. & - \\
\hline G. angustatum var. productum Grun. & + \\
\hline Gomphonema spp. & - \\
\hline Hannaea arcus (Ehrenb.) Patr. & ++ \\
\hline H. arcus var. amphioxys (Rabenh.) Patr. & + \\
\hline Hantzschia amphioxys (Ehrenb.) Grun. & ++ \\
\hline Luticola goeppertiana (Bletsch) Mann & - \\
\hline L. mutica (Kütz.) Mann & - \\
\hline L. muticopsis (V.H.) Mann & \\
\hline L. nivalis (Ehrenb.) Mann & \\
\hline Meridion circulare (Grev.) Ag. & • \\
\hline Navicula amphibola Cleve & - \\
\hline N. begeri Krasske & \\
\hline N. bryophila Petersen & \\
\hline N. cincta (Ehrenb.) Ralfs & \\
\hline N. [Diadesmis] contenta Grun. & + \\
\hline N. [Diadesmis] contenta fo. biceps (Grun.) Hust. & - \\
\hline N. [Diadesmis] contenta fo. paralella (Peters.) Hust. & - \\
\hline N. cuspidata (Kütz.) Kütz. & - \\
\hline N. [Diadesmis] gallica var. perpusilla (Kütz.) L.-B. & \\
\hline N. gracilis Ehrenb. & \\
\hline N. nivaloïdes Bock & \\
\hline N. radiosa var. tenella (Bréb. ex Kütz.) Grun. & \\
\hline N. rhyncocephala Kütz. & \\
\hline N. semen Ehrenb. & - \\
\hline Navicula spp. & + \\
\hline Neidium bergii (Cleve-Euler) Kramm. & \\
\hline N. bisulcatum (Lagerst.) Cleve & - \\
\hline Nitzschia fonticola Grun. & - \\
\hline N. ignorata Krasske & - \\
\hline N. tryblionella var. debilis A. Mayer & - \\
\hline Nitzschia spp. & + \\
\hline Orthoseira dendrophila (Ehrenb.) Crawford & \\
\hline O. dendroteres (Ehrenb.) Crawford & ++ \\
\hline O. roeseana (Rabenh.) O'Meara & ++ \\
\hline Orthoseira spp. & \\
\hline Pinnularia balfouriana Grun. ex Cleve & \\
\hline P. biceps Greg. & \\
\hline P. borealis Ehrenb. & ++ \\
\hline P. borealis var. restangularis Carlson & - \\
\hline P. divergentissima (Grun.) Cleve & - \\
\hline P. intermedia (Lagerst.) Cleve & - \\
\hline $\begin{array}{l}\text { Pinnularia spp. } \\
\end{array}$ & - \\
\hline Pseudostaurosira pseudoconstruens Will. \& Round & - \\
\hline Stauroneis agrestis Peterson & \\
\hline S. anceps Ehrenb. & - \\
\hline S. obtusa Lagerst. & \\
\hline S. phoenicenteron (Nitzsch) Ehrenb. & - \\
\hline Staurosira construens (Ehrenb.) Will. \& Round & - \\
\hline Staurosirella pinnata (Ehrenb.) Will. \& Round & \\
\hline Synedra ulna Ehrenb. & - \\
\hline Synedra spp. & - \\
\hline Tabellaria flocculosa (Roth) Kütz. Tabellaria spp. & - \\
\hline
\end{tabular}


powders were not classified into two separate groups (Table 1). The combined results from the two caves reveal a mixture of diatoms and other microfossils such as pollen, chrysophyte cysts, entire sponge and sponge spicules. The diatom flora in the floor ice and cryogenic calcite powders are dominated by aerophilous species, such as Hantzschia amphioxys, Orthoseira roeseana, N.(Diadesmis) contenta and Pinnularia borealis. Also frequently encountered are diatoms demonstrating a particular ecological tolerance to flowing or standing bodies of water. Among them, we find Hannaea arcus, a rheophilous taxon typical of flowing water (Patrick \& Reimer, 1966; Patrick, 1977), which attaches to rocks in cold water streams and rivers of mountainous regions (Patrick \& Reimer, 1966; Round et al., 1990). Also common is Didymosphenia geminata, a taxon found in the littoral zones or in streams and rivers of mountainous areas (Germain, 1981). Other nonaerophilous taxa are Cymbella spp., Eunotia praerupta and Stauroneis phoenicenteron..

\section{Diatoms in grus}

The sample of grus collected in the slope cave (PC-85) was analyzed for its diatom content and the results are presented in Table 1 (Column 3). The biotic content of the grus revealed numerous pollen types (Picea, Betula, Alnus) along with diatoms (9 taxa), dominated (approximately $85 \%$ ) by Orthoseira species. Luticola nivalis and forms of $N$, (Diadesmis) contenta and N. (Diadesmis) gallica var. perpusilla are also numerous (Table 1). These species can easily withstand long periods of drought (Germain, 1981). The remarkable state of preservation of Orthoseira dendroteres, a small genus of sub-aerial diatoms commonly found among bryophytes, and $O$. roeseana strongly suggests that they grew in situ inside the cave since their growth is stimulated by moist ambient air conditions, these diatom species likely develop along the walls from which they detach simultaneously with the rock crystals. Micro-gelivation, freeze / thaw cycles and dissolution were probably important factors in this process.

\section{DISCUSSION}

\section{Size of the caves and diatom relative abundance}

A total of 97 diatom species within 29 genera were identified in caves of Tsi-it-toh-Choh and Bear Cave ranges in the Ogilvie Mountains, northern Yukon Territory (Table 1). The greatest relative abundance of diatoms was found in Grande Caverne, followed by Caverne' 85 and PC- 85 . This difference in relative abundance is related to the size of the caves. For example, in Grande Caverne, which has a volume of nearly $1000 \mathrm{~m}^{3}$, 65 species were encountered. In Caverne'85, with a volume of $300 \mathrm{~m}^{3}$, 44 diatom species were counted and in $\mathrm{PC}-85$, the smallest with a volume of $7 \mathrm{~m}^{3}$, nine species were identified. This positive relation between the size of the cave and the relative amount of diatoms is explained by the fact that in larger caves, there is a possibility for more sites to trap the diatoms. Another explanation is related to air circulation dynamics in caves. Since approximately $80 \%$ of the identified diatoms have an aerophilous origin, air circulation and exchange with the outside is more important in caves with a large entrance, thus resulting in a greater abundance of diatoms being transported inside the larger caves.

\section{Type of sediment and diatom relative abundance}

Among the different media from which the diatom flora was compiled, the cryogenic calcite powders and the floor ice provided the most diversified species of diatoms, with a total of 58 diatom species depicting various biotopes. The grus contained the least amounts of diatom species, with nine taxa, but had the greatest absolute abundance. The ice stalagmites and the ice plugs yielded a total number of 29 and 42 diatom species respectively.

As shown in Figure 9, Eunotia praerupta, Hantzschia amphioxys, Orthoseira roeseana and Stauroneis obtusa are diatom species that tend to be mainly associated with the cryogenic calcite powders. The variety of identified diatoms in the cryogenic calcite powders is an indication that the latter function as very efficient

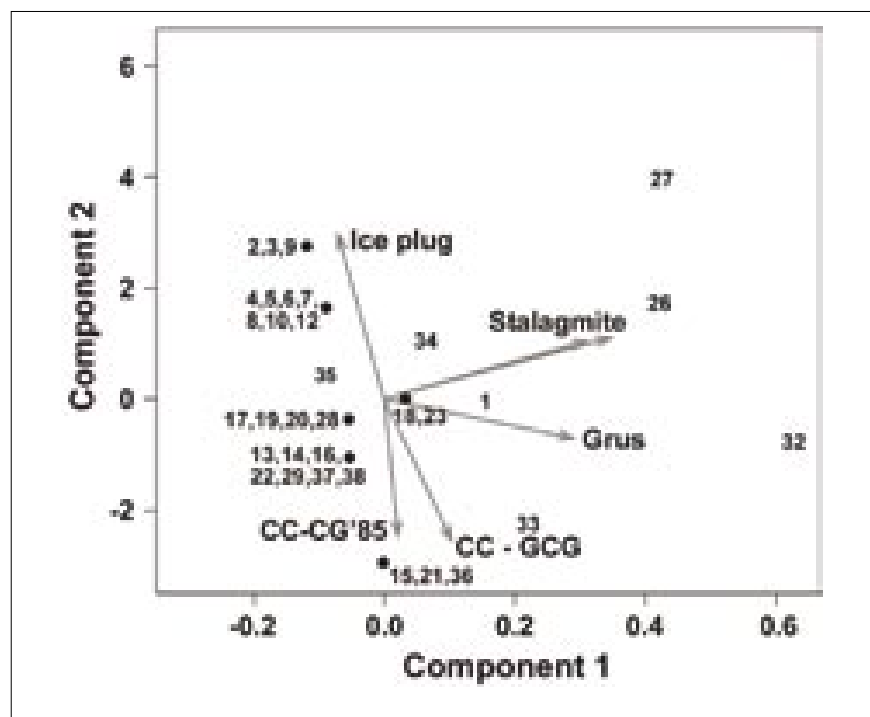

Fig. 9. A principal component analysis of the diatom species collected from ice plugs, ice stalagmites, cryogenic calcite powders and grus. The results of the PCA analysis revealed that component 1 and component 2 represents $38 \%$ and $29 \%$ of the variability of the data respectively. Ice plug GC \& CdM = ice plug in Grande Caverne and Caverne des Meandres; Ice plug C'85 = ice plug in Caverne'85; Stalag. = stalagmites collected in Grande Caverne and Caverne'85; $\mathrm{CCC}=$ cryogenic cave calcite powders and ice floor diatoms collected in Caverne' 85 and Grande Caverne.

Table 1. Diatom flora in freezing and slope caves in the Northern Yukon Territory, Canada. The fields named CC-GC and CC-C'85 = cryogenic cave calcite powders collected in Grande Caverne and Caverne' 85 respectively. The field named ICE PLUG CDM and ICE PLUG CG' 85 = ice plug sampled in Caverne des Méandres and Caverne' 85 respectively. The field named CODE represents the numbers in the principal component analysis, Figure 9.

\begin{tabular}{|c|c|}
\hline \multicolumn{2}{|c|}{ Legend } \\
\hline++ & Abundant $(>80 \%)$ \\
\hline+ & Frequent, common $(80-10 \%)$ \\
\hline$\bullet$ & Occasional, rare $(<10 \%)$ \\
\hline Blank & Absent \\
\hline
\end{tabular}


receptacles for diatoms: the diatoms are brought inside the cave by air circulation and are deposited on various ice formations. Diatoms are mixed with cryogenic calcite when ice sublimates. The aerial dispersion of diatoms is a well-known and effective medium of transport (Maguire, 1963; Pye, 1987). The warm air entering the caves during summer contains diatoms originating from the biotopes located near the entrance of the caves, or from external habitats (pool, creek and fall). The latter are incorporated in the hoar, ice plug and ice stalagmite formations in the caves. Since the diatoms contained in the cryogenic calcite powders result from the accumulation of diatoms from various media, such as sublimation of the floor ice or partial thaw of hoar, ice plug, ice stalagmite or snow, the cryogenic calcite powders have the most diversified diatoms species.

From Table 1, it is interesting to observe that the media with the lowest diatom diversity (grus, ice plug and ice stalagmite) tend to have the greatest relative abundance of diatoms, which is an indicative of highly specialized habitat. These diatoms are species growing in specific conditions and/or habitats. Based on Figure 9, Orthoseira spp. is dominant in the slope cave (grus), which can be a very dry environment; N.(Diadesmis) perpusilla, Orthoseira roseana group, N.(Diadesmis) contenta forms, Pinnularia borealis and P. balfouriana are common in the ice plug partially formed by snow accumulation (Caverne'85); N.(Diadesmis) gallica var. perpusilla, N.(Diadesmis) contenta (forms contenta, biceps and parallela), Achnanthes kryophila, Luticola nivalis, L. nivaloides, Orthoseira dendroteres and $O$. dendrophila are abundant in ice stalagmites present at the entrance of the freezing caves (Caverne'85 and Grande Caverne), which is a semi-dark, cold and wet environment.

\section{CONCLUSION}

The systematic enumeration of diatoms found in ice and calcite-rich sediments shows that the aerial transport and dispersion of diatoms is an efficient but limited process in caves of the northern Yukon Territory. Approximately 20\% of diatoms are allochtonous and originate from external biotopes and habitats (pool, creek and fall), with the remaining $80 \%$ of diatoms from subaerial habitats in nearby cave entrances. The distribution of diatoms in the caves is mainly associated with the condensation of water vapour along the walls. In this case, the distribution of diatoms suggests that the water vapour doesn't travel deep inside the caves, as it was observed by Roldan et al. (2004) in Spanish caves. The cold walls of the cave would cause the condensation of water vapour, which would limit the distance to which aerosols travel in condensation caverns. In freezing caves, where the mean annual air temperature is less than $0^{\circ} \mathrm{C}$, condensation results in important accumulation of hoar ice.

Beyond the hoar ice zone, the passages in the caves in northern Yukon Territory are very dry (Lauriol et al., 1988). This condition is unfavourable for the conservation of diatoms, but favourable for the conservation of macro-remains, such as woods and bones, and for the preservation of a red line of anthropogenic origin in Tsi-tse-Han Cave (Lauriol et al., 2001). For the same reason, it is possible that during the Last Ice Age in southern Europe, the drawing and painting on the walls by prehistoric people were possible only in the inner parts of the caves: the zone near the entrance was probably too humid and covered by ice which prevented the display of artwork, as suggested by d'Errico et al. (2000).

Finally, this study allows to propose that numerous natural or anthropogenic aerosols the size of diatoms, such as wood charcoal as well as calcium, magnesium and silica ions, can penetrate the caves and be deposited on carbonate substracta. This aerial transport of material, as opposed to transport by groundwater circulating through micro-fissures, should be considered as a possible alternative of transporting micro-size particles in sediments. The air currents can transport particles greater than the size of the tube that feed the stalagmites and stalactites (< $50 \mu \mathrm{m}$; Krivacsy \& Molnar, 1998) and are deposited mainly in areas of condensation in the karst system.

\section{ACKNOWLEDGEMENTS}

We are grateful to the people of Old Crow for their support of our work on their lands, and to students (Caroline Duchesne, Yanie Chauret, Éric Deschamps and Yanick Cabana) for their assistance in the field. Our work was generously supported by the National Science and Engineering Research Council of Canada through operating grants to B. Lauriol (NSERC OPG 007995). The Polar Continental Shelf Project provided logistical support in the field. We also wish to thank K. Lavoie (Plattsburg, USA), D.C. Ford (Hamilton, Canada) for their comments on a previous version of the manuscript and J. De Waele and two anonymous referees for their constructive review of the manuscript.

\section{REFERENCES}

Balch E.S., 1900 - Glacières or Freezing Caverns. Philadelphia, Allen, Lane and Scott, 337 p.

Bahls L.L., 1981 - Diatoms of Lewis and Clark Caverns. Proceedings of the Montana Academy of Sciences, 40: $11-18$.

Barber H.G. \& Haworth E.Y., 1981 - A Guide to the Morphology of the Diatom Frustule. Freshwater Biological Association, Scientific Publication, Printed by Titus Wilson \& Son, Kendal, 112 p.

Battarbee R.W., 1986 - Diatom analysis. In: Berglund B.E. (Ed.), Handbook of Holocene Palaeoecology and Palaeohydrology. Wiley, Chichester: 527-570.

Camburn K.E., 1982 - Subaerial diatom communities in eastern Kentucky. Transactions of the American Microscopical Society, 101: 375-387.

Carter J.R., 1971 - Diatoms from the Devil's Hole Cave, Fife, Scotland. Nova Hedwigia, 21: 657-684.

Clark I.D. \& Lauriol B., 1992 - Kinetic enrichment of stable isotopes in cryogenic calcites. Chemical Geology, 102: $217-228$. 
Claus G., 1955 - Algae and their mode of life in the Báradla Cave at Aggtelek. Acta Botanica Academiae Scientiarum Hungaricae, 2: 1-26.

Claus G., 1962a - Beiträge zur Kenntnis der Algenflora der Abaligeter Höhle. Hydrobiologia, 19: 192-222.

Claus G., 1962b - Data on the ecology of the algae of Peace Cave in Hungary. Nova Hedwigia, 4: 55-79.

Claus G., 1964 - Algae and their mode of life in the Báradla Cave at Aggtelek, II. Int. J. Speleol., 1: 13-17.

Dayner D.M. \& Johansen J. R., 1991 - Observations on the algal flora of Seneca Cavern, Seneca County, Ohio. Ohio J. Science, 3: 118-121.

d'Errico F., Vanhaeren M, Grousset F., Goni M.F.S., Valladas H. \& Rigaud J.P., 2000 - Les possibles relations entre l'art des cavernes et la variabilité climatique rapide de la dernière période glaciaire. In: Barrandon J.N., Guiber P. \& Michel V. (Eds.), Datation. Actes des XXIe rencontres Internationales d'Archéologie et d'Histoire d'Antibes (19-21 octobre 2000). Juan-les-Pins, Editions APDCA: 333-347.

Dobat K., 1970 - Considérations sur la végétation cryptogamique des grottes du Jura Souabe (sud-ouest de l'Allemagne). Annales de Spéléologie, 25: 871-907.

Douglas M.S.V. \& Smol J.P., 1994 - Limnology of High Arctic ponds (Cape Herschel, Ellesmere Island, N.W.T.). Archiv fur Hydrobiologie, 131: 401-434

Environment Canada, 2004 - Canadian Climate Normals 19712001. Canada Atmospheric Environment Service, Minister of Supply and Services Canada, Ottawa, Ontario, Canada.

Foged N., 1971 - Diatoms found in a bottom sediment sample from a small deep lake of the Northern Slope, Alaska. Nova Hedwigia, 21: 923-1035.

Foged N., 1981 - Diatoms in Alaska. Bibliotheca Phycologica, 53, J. Cramer, Vaduz, Germany. 317 p.

Ford D.C. \& Williams P.W., 1989 - Karst Geomorphology and Hydrology. Unwin Hyman, London, 601 p.

Fukuchi S., 1967 - Diatoms of Akiyoshi Cave and Kotoo River in relation to death by drowning. Nagasaki Igakkai Zassi, 42: 1029-1045.

Germain H., 1981 - Flore des diatomées, eaux douces et saumâtres. Société des Nouvelles Éditions, Paris, $444 \mathrm{p}$.

Glossary of Geology, 2005 - Nuendorf, K.K.E., Mehl, Jr., J.P. \& Jackson, J.A. (Eds.), American Geological Institute, Alexandria, Virginia, 779 p.

Gounot A.M., 1968 - Quelques observations sur le micropeuplement des limons des grottes Arctiques. In: Communication VIIIe Congrès National de Spéléologie, Draguignan: 226-236.

Hamilton P.B., Douglas M.S.V., Fritz S.C., Pienitz R, Smol J.P. \& Wolfe A. P., 1994 - A compiled freshwater diatom taxa list for the arctic and subarctic regions of North America. In: Hamilton P.B. (Ed.), Proceedings of the fourth ArcticAntarctic Diatom Symposium. Canadian Technical Report of Fisheries and Aquatic Sciences, Ottawa: 85-102.

Hartley B., 1986 - A check-list of the freshwater, brackish and marine diatoms of the British Isles and adjoining coastal waters. Journal Marine Biology Association of the U.K., 66: 531-610.

Haworth N.Y., 1980 - Comparison of continuous phytoplankton records with the diatom stratigraphy in the recent sediments of Blelham Tarn. Limnology Oceanography, 25: 1093-1103.
Hein M. K., 1990 - Flora of Adak Island, Alaska: Bacillariophyceae (diatoms). Bibliotheca Diatomologica, 21, Berlin, J. Cramer, 133 p.

Höeg O. A., 1946 - Cyanophyceae and bacteria in calcareous sediments in the interior of limestone caves in NordRana, Norway. Nytt Magasin for Naturvidenskapene, 85: 99-104.

Kashima N., IrieT. \& Kinoshita N., 1987 - Diatom, contributors of coralloid speleothems, from Togawa-Sakaidani-Do Cave in Miyazaki Prefecture, Central Kyushu, Japan. Int. J. Speleol., 16: 95-100.

Kellogg D.E. \& Kellogg T.B., 1996 - Diatoms in South Pole ice: implications for eolian contamination of Sirius Group deposits. Geology, 242: 115-118.

Kol E., 1957 - Algological investigations in the icecave of the Sator Mountain. Botanikai Közlemények, 47: 43-50.

Krammer K. \&Lange-Bertalot H., 1986 -Bacillariophyceae. 1. Teil: Naviculaceae. Süsswasser flora von Mitteleuropa, Band 2/1. Gustav Fischer Verlag: Stuttgart, New York.

Krammer K. \&Lange-BertalotH., 1988 - Bacillariophyceae. 2. Teil: Bacillariaceae, Epithemiaceae, Surirellaceae. Süsswasserflora von Mitteleuropa, Band 2/2. VEB Gustav Fischer Verlag, Stuttgart, Jena.

Krammer K. \&Lange-Bertalot H., 1991 - Bacillariophyceae. 3. Teil : Centrales, Fragilariaceae, Eunotiaceae. Süsswasserflora von Mitteleuropa, Band 2/3. Gustav Fischer Verlag: Stuttgart, Jena.

Krivacsy Z. \& Molnar A., 1998 - Size distribution of ions in atmospheric aerosols. Atmospheric Research, 46: 279-291.

Lacelle D., Lauriol B. \& Clark I.D., 2004 - Seasonal isotopic imprint in moonmilk from Caverne de l'Ours (Quebec, Canada): Implications for climatic reconstruction. Canadian J. Earth Sciences, 41: 1411-1423.

Lange-Bertalot H. \& Krammer K., 1989 - Achnanthes, Eine Monographie der Gattung. Bibliotheca Diatomologica, 18. Berlin, J. Cramer, 393 p.

Lauriol B., Carrier L. \& Thibaudeau, P., 1988 Topoclimatic zones and ice dynamics in the caves of the northern Yukon. Arctic, 41: 215-220.

Lauriol B., Clark I. D. \& Prévost C., 1995 - Étude d'une glace de la fin de l'Hypsitermal dans une caverne $d u$ Nord du Yukon, Canada. Série Géographie No. 34. Actes du $3^{\text {e }}$ Symposium International, Cavités Glaciaires et Cryokarst en Régions Polaires et de Haute Montagne, Chamonix-France, $1^{\text {er }}$ au 6 novembre 1994, Annales Littéraires de l'Université de Besançon, No.561: 89-92.

Lauriol B., Ford D.C., Cinq-Mars J. \& Morris W., 1997 - The chronology of speleothem deposition in Northern Yukon and its relationship to permafrost. Canadian J. Earth Sciences, 36: 1645-1654.

Lauriol B., Prévost C., Deschamps E., Cinq-Mars J. \& Labrecque S., 2001 - Faunal and archaeological remains as evidence of climate change in freezing caverns, Yukon Territory, Canada. Arctic, 54: 135-141.

Lauriol B., Lacelle D. \& Clark I.D. 2006 - Cryogenic carbonate powders in freezing caves. $2^{\text {nd }}$ International Workshop on Ice Caves. Demänovska dolina, Slovak Republic, May 8-12, 2006. Volume of abstracts. 
Lewin J.C., 1962 - Silicification. In: Lewin R.A.(Ed.), Physiology and Biochemistry of Algae. New York, Academic Press: 445-455

Maguire B. Jr., 1963 - The passive dispersal of small aquatic organisms and their colonization of isolated bodies of water. Ecological Monographs, 33: 161-185.

Mason-Williams M.A., 1967 - Further investigations into bacterial and algal populations of caves in South Wales. Int. Journal of Spel., 2: 389-395.

Mitter P., 1983 - Frost features in the karst regions of the West Carpathian Mountains. In $4^{\text {th }}$ International Conference of Permafrost (Fairbanks - Alaska), Washington D. C., July 17-22: 861-865.

Norris D.L., 1980 - Geology of Northern Yukon and Northwest District of Mackenzie. Geological Survey of Canada. Map 1581A.

Palik P., 1960 - Study into the algal flora of caves. Hidrológiai Közlöny, 40: 417-422.

Patrick R., 1977 - Ecology of freshwater diatoms and diatom communities. In: Werner D., (Ed.), The Biology of Diatoms, Botanical Monographs, 13: 284-332.

Patrick R. \& Reimer C.W., 1966 - The Diatoms of the United States, Exclusive of Alaska and Hawaii. Academy of Natural Sciences of Philadelphia Monographs, 1: $688 \mathrm{p}$.

Patrick R. \& Reimer C.W., 1975 - The Diatoms of the United States, Exclusive of Alaska and Hawaii. Academy of Natural Sciences of Philadelphia Monographs, 1: $213 \mathrm{p}$.

Prévost C., 1992 - Flore de diatomées des remplissages de cavernes, Yukon septentrional. Programme et Résumés de la Réunion Annuelle de l'AQQUA, Université d'Ottawa. Bulletin de l'AQQUA, 18: 38.

Pye K., 1987 - Aeolian Dust and Dust Deposits. Academic Press, Harcourt Brace Jovanovich, Publishers, 334 p.

Roldan M., Clavero E., Canals T., Arino X., GomezBolea A., Arino X., \& Hernandez-Marine M., 2004 -
Distribution of phototrophic biofilms in cavities (Garraf, Spain). Nova Hedwigia, 78: 329-351.

Round F.E., Crawford R.M. \& Mann D.G., 1990 - The Diatoms. Biology and Morphology of the Genera, Cambridge University Press, Cambridge, 747 p.

Rushforth S.R., Kaczmarska I.. \& Johansen J.R., 1984 - The subaerial diatom flora of Thurston Lava Tube, Hawaii. Bacillaria, 7: 135-157.

St. Clair L.L. \& Rushforth S.R., 1978 - The diatom flora of the Goshen playa and wet meadow. Nova Hedwigia, 29: 191-229.

St. Clair L.L., Rushforth S.R. \& Allen J.V., 1981 - Diatoms of Oregon Caves National Monument, Oregon. The Great Basin Naturalist, 41: 317-332.

Sweeting M.M. 1972. - Karst Landforms, MacMillan. London, $362 \mathrm{p}$.

Tarhule-Lips R. \& Ford D.C., 1998 - Condensation corrosion in caves on Cayman Brac and Isla de Mona, Puerto Rico. J. Caves and Karst Studies, 60: 84-95.

Thomas D.N., 2004 - Frozen Oceans: the Floating World of Pack Ice. Natural History Museum, 224 p.

Thomas D.N. \& Dieckmann G.S., 2003 - Sea Ice: An Introduction to its Physics, Chemistry, Biology and Geology, Malden M.A., Blackwell Publishing, Oxford, 402 p.

van Landingham S.L., 1965 - Diatoms from Mammoth Cave, Kentucky. Int. J. Spel., 1: 517-539.

van Landingham S.L., 1966 - Three new species of Cymbella from Mammoth Cave, Kentucky. Int. J. Spel., 2: 133-136.

van Landingham S. L., 1967 - A new species of Gomphonema (Bacillariophyta) from Mammoth Cave, Kentucky. Int. J. Spel., 2: 405-406.

Zupan Hajna N., 2003 - Chemical weathering oflimestones and dolomites. Speleogenesis and Evolution of Karst Aquifers, 1: 1-6. 